\title{
Towards an alternative 'worldview' of participation
}

\begin{abstract}
This article will draw on the author's experience in conducting participatory surveys in Singapore to offer alternative conceptualizations and versions of participation. The aim is to encourage self-reflection on the assumptions and expectations that participatory researchers carry with them into the field. Ultimately, how a group of people respond and interact with the idea of participation is going to vary widely depending on a whole host of circumstances, not all of which are observable and measurable. ${ }^{1}$ It is thus the conviction of this article that participatory endeavors have to do their best to be aware of local specificities and community dynamics that might cause research encounters to seem 'messy', and that researchers should think twice before classifying these as 'failures'. ${ }^{2}$ As irreducible individuals, our respondents show participation in various ways, not all of which involve noise or enthusiastically interacting with another, especially if that person is someone of authority which he/ she has reason to fear. ${ }^{3}$
\end{abstract}

Keywords: participation, political engagement and debate, research traditions, established theories, self-reflection, language, non-translatability
Volume 3 Issue 2 - 2019

\author{
Lynn $\mathrm{Ng}$ \\ Department of Political Science, University of Victoria, Canada
}

Correspondence: Lynn Ng, PhD Candidate in Political Science, University of Victoria, 3800 Finnerty Rd,Victoria, BCV8P 5C2, Canada,Tel (250) 72I-72II, Email lynnngyuling@uvic.ca

Received: January 01, 2019 | Published: March 27, 2019

\section{Introduction}

The concept of 'Participation' has become main stream in many research circles today, including Political Science and International Relations. As championed by the World Bank (WB) and United Nations(UN) in particular, participation can be broadly conceived as an attempt to 'decenter the researcher' from their traditional position of power, to allocate as much autonomy as possible to participants. ${ }^{4}$ In some cases this might be an almost complete 'transfer' of power to participants, such that they are involved in every stage of the research process: identifying the pressing issues, formulating research questions, doing fieldwork and obtaining data, also writing it up or presenting it in their preferred format. ${ }^{5}$ The end-product in many cases might not fit the expected format of academic contributions, as participants may decide that other mediums like drawing, music or video making suit their interests more. Overall, there is a huge, and I would argue overrated, emphasis on the idea of speaking up in public and demonstrating visible involvement. ${ }^{6}$

\section{Research context and methods}

For reasons of privacy, I shall not disclose the name of the firm I did survey work for, nor the exact times and locations where this work took place. However, it was a private market research firm who were interested in finding out the opinions of local residents regarding the effectiveness of government communication and information dissemination strategies. I spent 14 days interviewing local residents in the designated areas on a house-to-house basis. The structure of the survey was such that I had a list of themes and questions in multiple choice formats, plus a few short structured questions. However they were not to be used if residents have their own contributions. Each survey started with a very broad question enquiring about the local minister's effectiveness in reaching out to the district population and providing them with updated information. They were also encouraged to provide general feedback on how the communication outreach system could be improved. The mode of answering was verbal which I would note down on an iPad. In this scenario, 'desirable' participation would be if the majority of my respondents took charge of the conversation by elaborating on their particular household/ personal situation, such that the survey template was not heavily used.

\section{Results and discussion}

The actual outcome, however, was not so rosy. A large majority (75\%) of my respondents ended up not giving an answer to the broad question such that I had to use the structured survey. Overwhelmingly, residents did not show an inclination to express political views or be involved in evaluating the survey questions themselves. Most provided monosyllabic answers before proceeding to fill out the closeended questions.

What was especially interesting to note, however, is that residents were enthusiastic about debating about politics in their own ways which is un measurable by the research tools at my disposal. Firstly, the political climate and tradition of Singapore must be taken into account. As a one-party state since independence, politics is widely considered a sensitive topic and might even constitute one of the 'Outof-Bounds' (OB) markers. ${ }^{7}$ This does not indicate that residents are apathetic or simply disinterested in political discussion. It does mean, however, that they carry it out in a myriad of other creative ways which cannot be publicly seen, for example in the household among family members, or with close friends. Another 'creative' and informal tactic which was highly used was not directly answering my question, but rather expressing their views, especially criticisms, of the government in other contexts unrelated to the topic of information communication. A prevalent example is offering to share negative experiences of income tax policies rather than communication policies. This way, there was no way I could document their critical views since the conversation was not geared to the survey's rubric. Thus there were a countless number of highly valuable interactions where residents expressed strong opinions, however due to the specific form these expressions took, I was unable to neither record them nor use them for official purposes of reporting back.

Secondly, and related to the attenuated political climate of Singapore, is the general fear of having one's controversial view made known in public circles. I observed a widespread reluctance to have one's critical views documented, which perhaps explained why many chose to take an indirect route by dodging the question while being critical. Also, most residents were visibly much more at ease when I put away the iPad, and that was when some of the strongest opinions 
were aired verbally. Looking back, I realized that residents perceived me as someone 'working for the government' since I was conducting a related survey. Hence they would be understandably reticent when asked to offer suggestions of how the government apparatus could be improved.

\section{Conclusion}

\section{Implications for participatory research}

Returning to the main contention of this article, the research encounters described above point to the 'messiness' of participation in terms of how it does not fit empirical research traditions. How individuals view participation is strongly linked with their experiences in education and the knowledge/resource base they can access. Prominent social identities that mediate one's 'worldview', in this sense, include socioeconomic background, class, gender and family upbringing among others. ${ }^{9}$ Thus among participants, simply because they have an identity in common such as 'woman', does not mean they will relate to the theme of 'Gender' in similar ways. ${ }^{10}$ It is particularly pertinent for social researchers to be sensitive towards such 'idiosyncrasies' in participatory interactions, which often contradict established theories of human behavior.

In addition would be the problems of Language, broadly conceived as a colonial tendency to work solely within the narrow boundaries of the English language. ${ }^{11}$ To do justice to participants would mean paying attention to the social atmosphere and general sentiment surrounding the encounter. This may not be amenable to literary representation and written expression, as theorists of Affect propose. In Singapore, there are four official languages including English, plus three mother tongues: Chinese Mandarin, Malay and Tamil. ${ }^{12} \mathrm{~A}$ whole host of other dialects within these mother tongues also exist, the most common ones being Hokkien and Teochew. Also, English was legislated as a national language only in 1965, which meant a lot of my older respondents only spoke their dialect/mother tongue and had very limited English proficiency. These technical barriers aside, the larger argument is that languages can be seen as systems which mediate affect, ie. Linguistic affect. ${ }^{13}$ That is, it is not a far stretch to argue that we change personality or the way we think/interpret depending on the language space we are occupying. ${ }^{14}$ Given that many of my respondents did not speak English as a native language, there would be huge mistranslations of their original intention or intensity of their expressions. This issue of non-translatability is largely seen as un resolvable, because language systems simply are unable to 'access' and fully inhabit one another. ${ }^{15}$ This does not mean our research is futile, ${ }^{16}$ however, but instead of using data translated into English to prescribe what others should do, perhaps it would do better on those in the academy to use that for self-reflection instead, ie. Asking what English is unable to cover.

\section{Acknowledgments}

None.

\section{Conflicts of interest}

The author declares that there are no conflicts of interest.

\section{References}

1. Pain R, Francis P. Reflections on participatory research. Area 2003;35(1):46-54.

2. Kesby M. Retheorizing empowerment-through-participation as a performance in space: Beyond tyranny to transformation. Signs: Journal of Women in Culture and Society. 2005;30(4):2037-2065.

3. Pain R, Kindon S. Participatory geographies. Environment and Planning A. 2007;39(12):2807-2812.

4. Cahill C, Sultana F, Pain R. Participatory ethics: politics, practices, institutions. ACME: An International E-Journal for Critical Geographies. 2007;6(3):304-318.

5. Hodge P, Lester J. Indigenous Research: Whose Priority? Journeys and Possibilities of Cross-Cultural Research in Geography. Geographical Research. 2006;44(1):41-51.

6. Fine M. Working the Hyphens: Reinventing Self and Other in Qualitative Research. In: Lincoln YS, Denzin NK, editors. Handbook of qualitative research. US: Sage; 1994. pp. 70-82.

7. Huang S, Yeoh BS. Ties that bind: state policy and migrant female domestic helpers in Singapore. Geoforum. 1966;27(4):479-493.

8. Stoecker R. Are academics irrelevant? Roles for scholars in participatory research. American Behavioral Scientist. 1999;42(5):840-854.

9. Stoudt BG, Fox M, Fine M. Contesting privilege with critical participatory action research. Journal of Social Issues. 2012;68(1):178193.

10. Minh Ha TT. Not you/like you: Postcolonial women and the interlocking questions of identity and difference. Cultural Politics. 1977;11(2):415419.

11. Spivak GC. Can the subaltern speak? In: Nelson C, Grossberg L, editors. Marxism and Interpretation of Culture. Chicago: University of Illinois Press; 1988. pp. 271-313.

12. Tan C. Globalisation, the Singapore state and educational reforms: Towards performativity. Education, Knowledge \& Economy. 2008;2(2):111-120

13. Ahmed S. The Cultural Politics of Emotion. 2nd ed. USA/Canada: Routledge; 2015.44 p.

14. Butler J. Frames of War: When is Life Grievable? London/New York: Verso; $2009.62 \mathrm{p}$.

15. Spivak GC. Translation as culture. Parallax. 2000;6(1):13-24.

16. Kindon SL. Thinking-through-Complicity' with Te Iwi o Ngāti Hauiti. Towards a Critical Use of Participatory Video for Research. New Zealand: Doctoral dissertation, University of Waikato; 2012. 261 p. 